\title{
APLIKASI SISTEM SURVEI PERSEPSI LAYANAN DAN PERSEPSI KORUPSI PADA KANTOR IMIGRASI KELAS I NONTPI PALANGKA RAYA BERBASIS FRAMEWORK CODEIGNITER
}

\author{
Agung Prabowo', Fenroy Yedithia', Ika Safitri Windiarti', Achmad Rizal Kurniawan' \\ 'Program Studi Sistem Informasi, STMIK Palangka Raya , Jalan G. Obos, No. I I4, \\ Palangka Raya \\ ${ }^{2}$ Program Studi IImu Komputer, Universitas Muhammadiyah Palangkaraya, Jalan RTA \\ Milono Km I,5, Palangka Raya \\ Email: agungdosen@gmail.com
}

\begin{abstract}
ABSTRAK
Penggunaan teknologi informasi dapat membantu memudahkan kantor dalam menghitung sistem survei sehingga dapat melayani dengan cepat, tepat dan profesional. Sehingga tidak perlu lagi kertas sebagai sarana pengisian survei. Metode yang digunakan dalam penelitian ini meliputi metode observasi, metode wawancara, metode literatur, metode dokumentasi, teknik dan alat analisis menggunakan Alat Unified Modelling Language (UML), metode pengujian dan metode pengujian menggunakan Black Box Testing. Hasil penelitian ini telah berhasil dilaksanakan menjadi informasi yang dapat membantu dalam proses perhitungan survei. Hasil penelitian ini juga telah diuji menggunakan pengujian Black Box pada hasil pelaksanaannya. Hasil pengujian sistem menggunakan pengujian Kotak Hitam seperti yang diharapkan. Berdasarkan hasil kuesioner, yaitu total keseluruhan yang diperoleh nilai rata-rata $97,33 \%$. Sehingga dapat diasumsikan bahwa sistem yang dibangun penulis telah memenuhi nilai yang sesuai untuk publikasi.
\end{abstract}

Kata kunci: Codeigniter, framework, korupsi, layanan, persepsi, survei

\begin{abstract}
The use of information technology can help facilitate the office in calculating the survey system so that it can serve quickly, precisely and professionally. So that no longer need paper as a means of filling out the survey. The methods used in this research include observation methods, interview methods, literature methods, documentation methods, techniques and analysis tools using Unified Modelling Language (UML) Tools, testing methods and testing methods using Black Box Testing. The results of this study have been successfully implemented into information that can help in the survey calculation process. The results of this study have also been tested using Black Box testing on the results of the implementation. The test results of the system using the Black Box testing are as expected. Based on the results of the questionnaire, namely the overall total obtained an average value of $97.33 \%$. So it can be assumed that the system that the author built has met the appropriate value for publication.
\end{abstract}

Keywords: Codeigniter, framework, corruption, service, perception, survey

\section{PENDAHULUAN}

Perkembangan teknologi informasi saat ini terus berkembang, dapat dilihat dari munculnya internet. Sehingga saat ini hampir semua bidang membutuhkan internet sebagai sumber informasi. Sistem survei ini merupakan langkah awal reformasi birokrasi untuk melakukan penataan terhadap sistem penyelenggaraan pemerintahan yang baik, efektif dan efisien, sehingga dapat melayani masyarakat secara cepat, tepat, dan profesional.

Responden dapat memberikan pilihannya melalui kertas yang telah disediakan pihak kantor untuk mengisi survei tersebut. Sistem survei ini sudah biasa dilakukan dan ternyata tetap saja membutuhkan dana yang besar untuk biaya kertas. Membutuhkan beberapa orang staf dan waktu untuk mendapatkan hasil perhitungan survei. Melihat kondisi ini maka dilakukan pembuatan suatu alternatif pemilihan yang lebih mudah, dan cepat. Alternatif yang akan diteliti adalah memanfaatkan teknologi komputer.

\section{TINJAUAN PUSTAKA}

Menurut Prabowo (2020), aplikasi adalah program siap pakai yang dapat digunakan untuk menjalankan perintahperintah dari pengguna aplikasi tersebut dengan tujuan pembuatan aplikasi tersebut, aplikasi mempunyai arti 
Sistem Survei Persepsi Layanan Dan Persepsi Korupsi Pada Kantor Imigrasi Kelas INONTPI

Palangka Raya Berbasis Framework Codeigniter

yaitu pemecahan masalah yang menggunakan salah satu teknik pemrosesan data aplikasi yang biasanya berpacu pada sebuah komputasi yang diinginkan atau diharapkan maupun pemrosesan data yang diharapkan.

Framework adalah suatu struktur konseptual dasar yang digunakan untuk memecahkan atau menangangi suatu masalah kompleks. Istilah ini sering digunakan antara lain dalam bidang perangkat lunak untuk menggambarkan suatu desain sistem perangkat lunak yang dapat digunakan Kembali (Sidik, 2017). Menurut Agus Saputra. (2018) dan Raharjo (2015) Codeigniter adalah framework web untuk bahasa pemrograman PHP, yang dibuat oleh Rick Ellis pada tahun 2006, penemu dan pendiri EllisLab.

Pemodelan yang digunakan dalam penelitian ini adalah menggunakan Unified Modeling Language (UML). Menurut Fathansyah (2015) UML singkatan dari Unified Modeling Language.

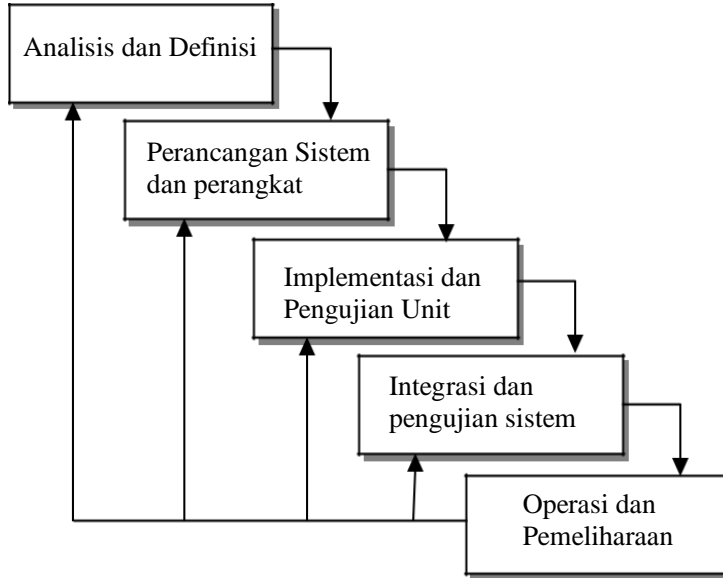

\section{Gambar I. Desain Unified Modelling Language (UML)}

UML Muncul karena adanya kebutuhan permodelan visual untuk menspesifikasikan, menggambarkan, membangun, dan dokumentasi dari sistem perangkat lunak (Munawar, 2018). UML Merupakan bahasa visual untuk permodelan dan komunikasi mengenai sebuah sistem dengan menggunakan diagram dan teks-teks pendukung.

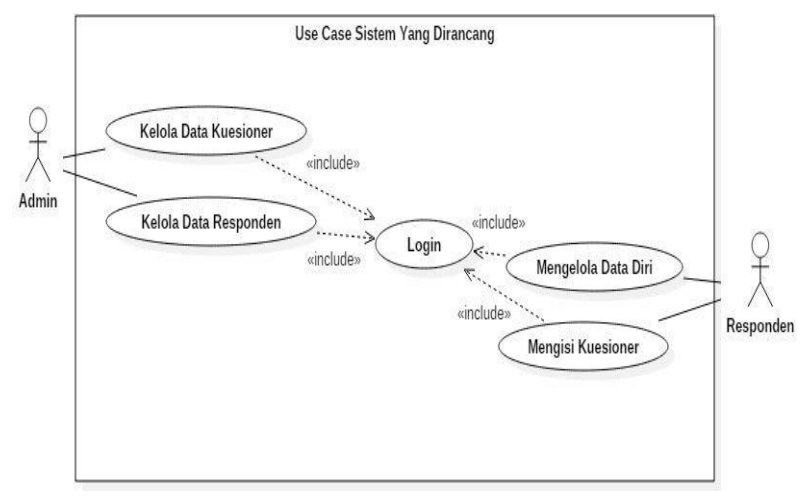

Gambar 2. Use Case Diagram

Menurut Sukamto dan Shalahuddin (2016) Use Case merupakan pemodelan untuk melakukan (behavior) sistem informasi yang dibuat. Use Case mendeskripsikan sebuah interaksi antara satu atau lebih aktor dengan sistem informasi yang dibuat.

\section{METODE PENELITIAN}

\section{I Metode Observasi}

Metode ini merupakan proses dimana penulis terjun langsung ke lapangan guna mendapatkan data dan informasi yang diperlukan guna mendukung penyelesaian penelitian ini.

\subsection{Metode Wawancara}

Metode ini penulis akan mengumpulkan data dengan melakukan tanya jawab secara langsung dengan narasumber yaitu Bapak Eko Juniarto selaku Kasi TIKIM (Teknologi Informasi Keimigrasian) yang berkaitan dengan penelitian ini yaitu tanya jawab perihal kebutuhan lainnya yang diharapkan dapat diterapkan nantinya. Dan dengan menggunakan data yang telah diberikan nantinya dapat menunjang pembuatan penelitian ini.

\subsection{Metode Dokumentasi}

Metode ini dilakukan pengumpulan data dengan cara dokumentasi tertulis maupun elektronik

\subsection{Metode Kepustakaan}

Metode pengumpulan data dengan cara mencari datadata yang diperlukan dari membaca dan mempelajari buku-buku yang berhubungan sebagai referensi. 


\section{IMPLEMENTASI DAN PEMBAHASAN}

\section{I Implementasi}

Pengimplementasian sistem yang telah dirancang dan dibangun ditujukan untuk melihat dan menganalisa mengenai kesesuaian sistem terhadap rancangan yang dibuat, dimana sistem tersebut akan melalui proses uji coba untuk melihat apakah sistem dapat bekerja sesuai yang diharapkan atau tidak. Implementasi tersebut meliputi: uji coba sistem, manual program, manual instalasi.

a) Implementasi Pengujian Login Admin sukses

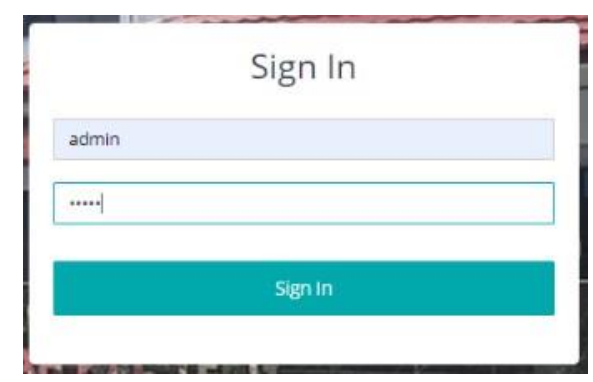

Gambar 3. Login Admin

b) Implementasi Pengujian Menu Beranda

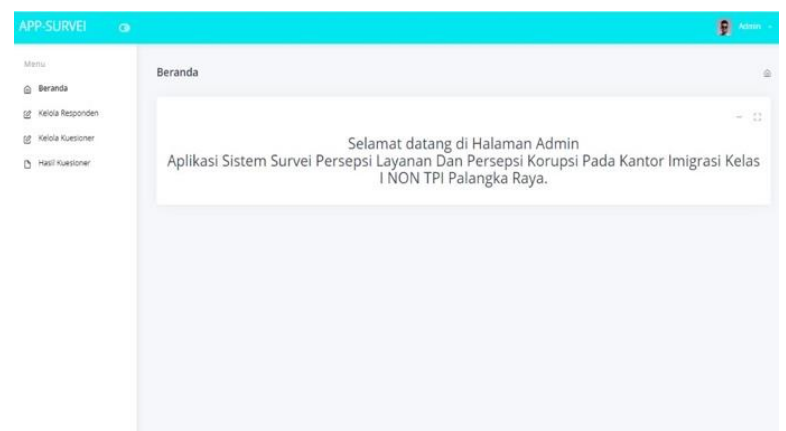

Gambar 4. Tampilan Menu Beranda c) Implementasi Pengujian Tambah Data

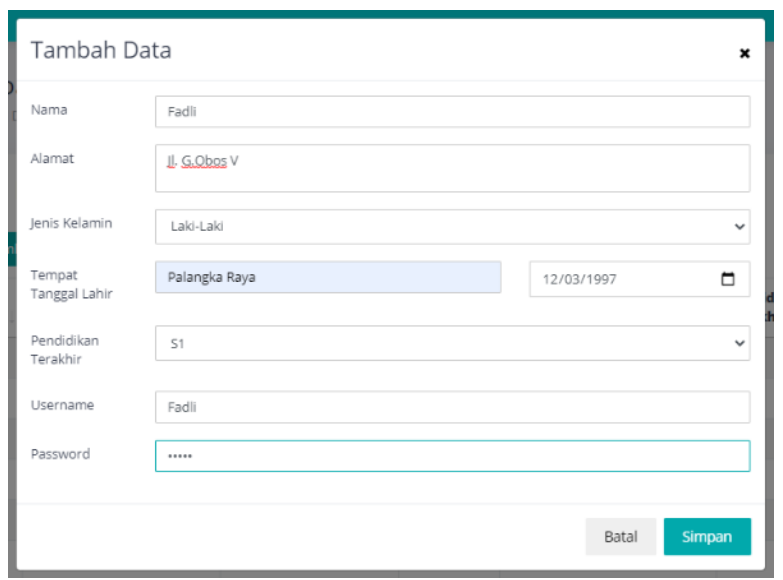

Gambar 5. Tampilan Tambah Data

d) Implementasi Pengujian Ubah Data Lokasi

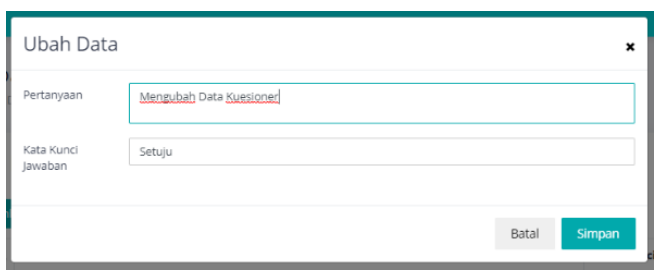

Gambar 6. Pengujian Ubah Data Kuesioner

e) Implementasi Pengujian Menu Barang

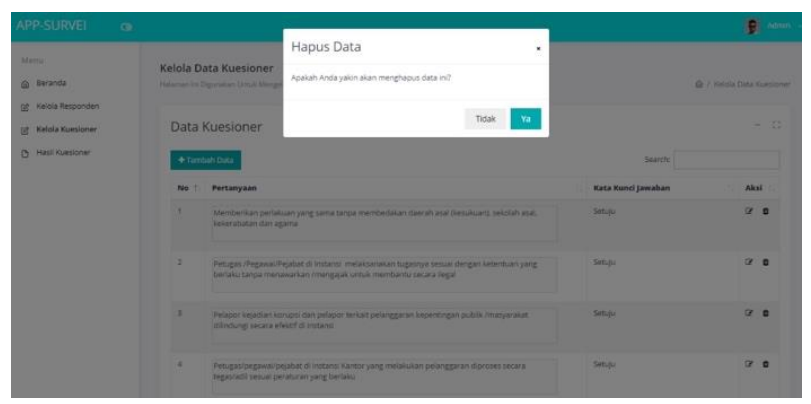

Gambar 7. Tampilan Hapus Data Kuesioner 


\section{Agung Prabowo, Fenroy Yedithia, Ika Safitri Windiarti \& Achmad Rizal Kurniawan Aplikasi 2021 \\ Sistem Survei Persepsi Layanan Dan Persepsi Korupsi Pada Kantor Imigrasi Kelas INONTPI \\ Palangka Raya Berbasis Framework Codeigniter}

f) Implementasi Pengujian Tampilan Hasil PerResponden

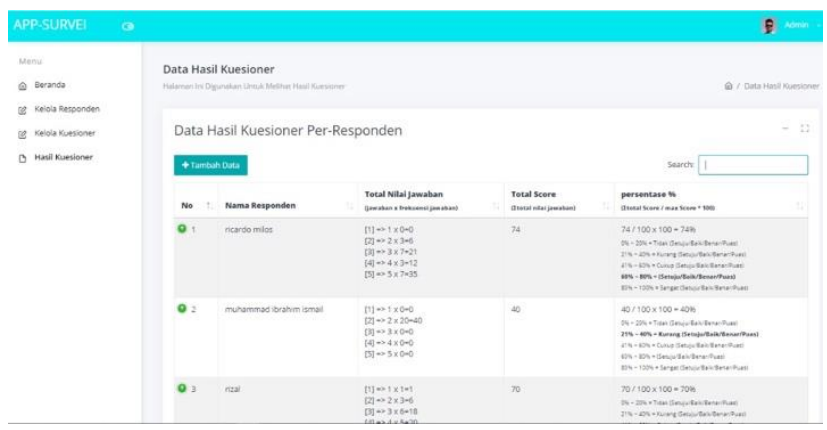

Gambar 8. Tampilan Hasil Per-Responden

g) Implementasi Pengujian Perhitungan PerKuesioner

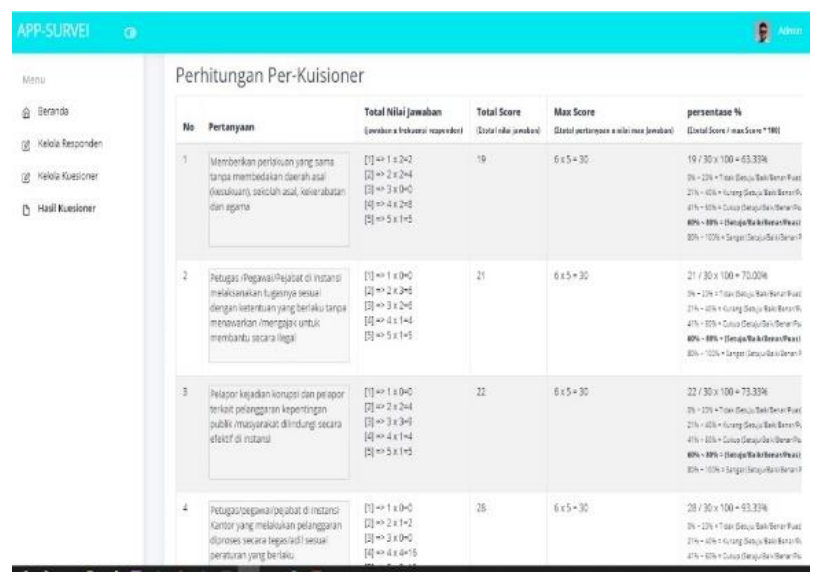

Gambar 9. Tampilan Perhitungan Per-Kuesioner

h) Implementasi Pengisian Kuesioner

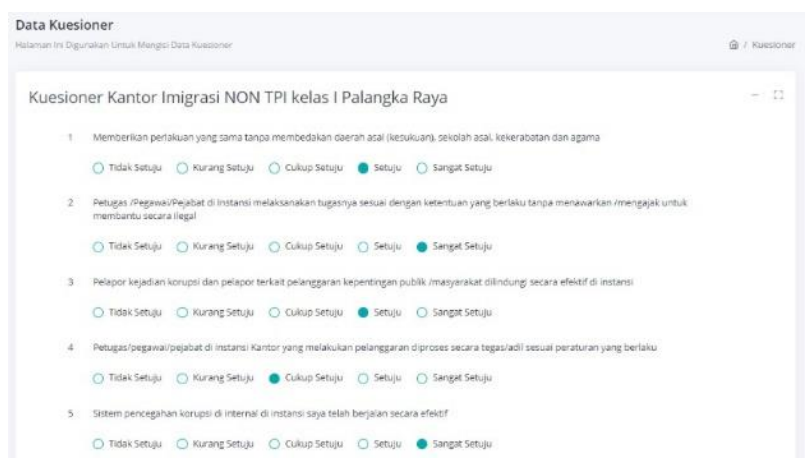

Gambar 10. Tampilan Pengisian Kuesioner

\subsection{Uji Coba Sistem dan Program}

Pada pembuatan sistem ini metode pengujian yang penulis gunakan yaitu metode pengujian Black Box.Pengujian black box berfokus pada persyaratan fungsional perangkat lunak. Pengujian ini memungkinkan analis sistem memperoleh kumpulan kondisi input yang akan mengerjakan seluruh keperluan fungsional program. Tujuan metode ini mencari kesalahan pada fungsi yang salah atau hilang, kesalahan pada interface, kesalahan pada struktur data atau akses database.

\subsection{Pembahasan Implementasi Sistem}

Berdasarkan wawancara yang telah dilakukan maka dapat diketahui bahwa proses survei, Responden yang datang dapat memberikan pilihannya melalui kertas yang telah disediakan pihak kantor untuk mengisi survei tersebut. Sistem survei ini sudah biasa dilakukan dan ternyata tetap saja membutuhkan dana yang besar untuk biaya kertas. Membutuhkan beberapa orang staff dan waktu untuk mendapatkan hasil perhitungan survei.

Dari wawancara tersebut juga diketahui bahwa: a. Sistem survei yang sedang berjalan masih menggunakan media kertas untuk melakukan pelayanan, sehingga memerlukan waktu yang lama.

b. Hasil perhitungaan suara dari total jumlah suara dihitung masih secara konvensional, sehingga ada kemungkinan campur tangan manusia yang dapat dapat mempengaruhi hasil hitungan.

Adapun Aplikasi Sistem Survei yang dibangun Dapat memberikan salah satu solusi kemudahan untuk mempermudah pihak kantor dalam meningkatkan pelayanan sehingga tercipta pelayanan yang cepat, dan efisien.

\section{KESIMPULAN DAN SARAN}

\section{I Kesimpulan}

Kesimpulan yang dapat diambil dari penelitian ini adalah sebagai berikut:

1. Aplikasi Sistem Survei Persepsi Layanan Dan Persepsi Korupsi Pada Kantor Imigrasi Kelas I NON TPI Palangka Raya Berbasis Web Framework Codeigniter yang dibangun berhasil dibuat dengan merancang terlebih dahulu aplikasi tersebut 
menggunakan aplikasi starUML lalu diterjemahkan ke dalam bentuk kode program framework codeigniter menggunakan aplikasi Sublime Text.

2. Berdasarkan dari hasil uji coba dengan menggunakan metode black-box testing dapat disimpulkan bahwa aplikasi yang dibangun telah sesuai dengan harapan dan didapatkan hasil. Berdasarkan hasil kuesioner yaitu total keseluruhan didapatkan nilai rata-rata sebesar $97,33 \%$.

3. Dengan adanya Aplikasi Sistem Survei Persepsi Layanan Dan Persepsi Korupsi Pada Kantor Imigrasi Kelas I NON TPI Palangka Raya ini, nantinya akan mempermudah pihak kantor dalam meningkatkan pelayanan sehingga tercipta pelayanan yang cepat, dan efisien.

\subsection{Saran}

Adapun saran dalam penggunaan dalam penggunaan maupun pengembangan sistem ini adalah diharapkan aplikasi ini dapat direalisasikan dalam peningkatan Sistem Survei sehingga perhitungan bisa lebih cepat dan efisien serta dapat membantu kinerja admin dalam mengelola pelayanan Sistem Survei tersebut agar dikemudian hari dapat lebih baik lagi dan berkembang sehingga mampu memberikan pelayanan yang baik.

\section{DAFTAR PUSTAKA}

Agus Saputra. 2018. Panduan dan Jitu Menguasai Framework Codeigniter 3. ASFA Solution. Bekasi.

Betha Sidik. 20I7. Pemograman Web dengan PHP 7. Informatika Bandung. Bandung.

Fathansyah. 20I5. Basis Data ( Revisi II ), Informatika Bandung. Bandung. Mulyani, S. 2016. Metode Analisis dan Perancangan Sistem. Abdi Sistematika. Bandung.

Munawar. 2018. Analisis Perancangan Sistem Berorientasi Obyek Dengan UML Unified Modeling Language, Informatika Bandung. Bandung.

Prabowo, A., 2020. Aplikasi E-Commerce Seragam Olahraga Pada Koperasi Hasanka Berbasis Web. Jurnal Sains Komputer Dan Teknologi Informasi, 3(I), Pp.I23-I27.

Raharjo, Budi. 2015. Belajar Otodidak Framework Codelgniter, Informatika. Bandung.

Sukamto, R. A., dan Shalahudin, M. 2014. Rekayasa Perangkat Lunak Terstruktur Dan Berorientasi Objek. Bandung: Informatika. Bandung. 